\title{
Psychologia jako niezbędny komponent politologii
}

II Kongres Politologir, KTÓRY OdBYŁ SIĘ WE WRZEŚNiU 2012 R., miał za zadanie przybliżyć, ale i skonfrontować różne stanowiska obecne w polskiej nauce. Celem tej pracy jest ukazanie psychologicznej perspektywy politologii. Jest ona rozszerzonym zapisem głosu w dyskusji, która była ustrukturalizowana w postaci panelu „Perspektywy politologii”. Tytuł pracy zawiera element wartościujący, którego użycie jest zabiegiem całkowicie świadomym.

W 2012 r. została wydana bardzo stymulująca intelektualnie książka Ryszarda Skarzyńskiego pt. Podstawowy dylemat politologii: dyscyplina nauki czy potoczna wiedza o społeczeństwie. O tradycji uniwersytetu $i$ demarkacji wiedzy. Stanowi ona podstawę do dalszych rozważań w niniejszej pracy.

Według autora książki przedmiotem poznania politologii jest to, co polityczne ${ }^{1}$. Kryterium wyróżniającym dane zjawisko spośród tych o charakterze społecznym, a które kwalifikuje je do grupy „polityczne” jest „sposób (w tym zakres) posługiwania się [zjednoczeń ludzi - przyp. M. B.] środkami w efekcie gotowości do przekształcania rzeczywistości”. Politologia jako nauka „zajmuje się badaniem tego szczególnego sposobu funkcjonowania ludzkich zbiorowości, który prowadzi do wyłaniania zjednoczeń zmierzających do ustanowienia z powołania i każdym środkiem powszechnego porządku wedle jego własnej wizji”" Przyjmuję to twierdzenie jako podstawowe ujęcie dla tego artykułu. Rzecz oczywista - istnieją również inne ujęcia, z którymi warto się zapoznać, aby zrozumieć przyczynę napisania przez R. Skarzyńskiego wspomnianej pracy ${ }^{3}$. Jednym z nich jest postulat biegunowo odmien-

${ }^{1}$ Pewne jest jednak, iż bardziej mowa w publikacji o postulacie zajmowania się tym, co polityczne, niż o opisie stanu faktycznego, w którym politologia wyzbyła się swojego przedmiotu poznania. Zob. R. Skarzyński, Podstawowy dylemat politologii: dyscyplina nauki czy potoczna wiedza o spoleczeństwie. O tradycji uniwersytetu i demarkacji wiedzy, Białystok 2012, s. 279.

${ }^{2}$ Ibidem, s. 296.

${ }^{3}$ Barbara Krauz-Mozer twierdzi bowiem, że politologia jest raczej konglomeratem 
ny, którego autorem jest Robert E. Lane. Twierdzenia R. E. Lane’a pozwalają na sformułowanie tezy, iż psychologia dysponuje narzędziami, ale i sama jest pryzmatem niezbędnym dla politologii w określeniu tego, co jest polityczne.

\section{Postulat uWolnienia Politologit Roberta E. Lane'A}

ROBERT E. LANE W ARTYKULE JAK UWOLNIĆ POLITOLOGIE OD NIEJ SAMEJ? interpretuje politologię następująco: „Politologia jest dyscypliną naukową w tym tylko sensie, że - podobnie jak literatura - jest wymieniana w programach studiów, ale nie w znaczeniu ogółu zjawisk analizowanych przez spójny zbiór teorii czy choćby rywalizujące z sobą spójne teorie - jak fizyka (...) jedynie rości sobie prawo do zestawu problemów, do których odnosi się wiele ujęć i teorii"4. Tym samym politologia jest definiowana przez przedmiot zainteresowania, także ten, który może być wyjaśniany przez inne dyscypliny naukowe, w szczególno-

innych dyscyplin, niż że stanowi ,jednolitą dyscyplinę naukową”. Inne podejście można odnaleźć u Andrew Heywooda, który zwraca uwagę na szereg problemów wynikających z tworzenia pojęć politycznych. Jednym z nich jest trudność oddzielenia pojęć politycznych od filozoficznych, moralnych, ideologicznych. Z tego zaś wynika kolejny problem dotyczący unaukowienia pojęć, które niosą z sobą komponent emocjonalny z powodu ideologicznego sporu, jaki wokół nich się toczy. A. Heywood podaje przykład pojęcia „demokracji”. Wyraża tym samym wątpliwość istnienia „zimnych” słów, odseparowanych od wartościowania. Ostatnim problemem wskazanym przez A. Heywooda jest tendencja do fetyszyzowania pojęć, co jest rozumiane jako traktowanie pojęć tak, ,jak gdyby cechowała je konkretna egzystencja, niezależna od posługujących się nimi ludzi, a w pewnym sensie mająca nawet nad nimi władzę”. Na przykładzie „typów idealnych” Maxa Webera, konstatuje, iż „lepiej myśleć o pojęciach czy typach idealnych nie w kategorii «prawdy» czy «fałszu», lecz większej bądź mniejszej «użyteczności»”.

${ }^{\mathrm{w}}$ tym sensie naukowiec zmuszony jest dobierać odpowiednie językowe narzędzie służące opisowi badanego zjawiska, a zatem - pośrednio - odwoływać się do tych z innych dziedzin. Przykładowo, słowo „reżim” stanowi problem dla badacza. Z jednej strony, funkcjonuje ono jako synonim totalitaryzmów. Z drugiej strony, jest określeniem politologicznym, pomocnym przy opisie zasad w stosunkach (formalnych i nieformalnych) między władzą a społeczeństwem. Osobnym problemem jest aneksja pojęć z innych dziedzin, np. nauk przyrodniczych. Reżim bowiem jest określeniem odnoszącym się do przepływu wody w rzece. Zob. A. Heywood, Teoria polityki. Wprowadzenie, Warszawa 2009, s. 15-16; Gmyz: Potraktowali mnie tak samo jak reżim traktowat dziennikarzy w stanie wojennym, „Gazeta.pl”, http://wiadomosci.gazeta.pl/wiadomosci/1,114871,12801392,Gmyz_Potraktowali_mnie_tak_samo_jak_rezim_traktowal. html, o6.11.2012 r.; B. Krauz-Mozer, Teorie polityki. Założenia metodologiczne, Warszawa 2005, s. 15; Leksykon politologii wraz z aneksem reforma samorzadowa $w$ Polsce, partie, parlament, wybory (1989-1997), red. A. Antoszewski, R. Herbut, Wrocław 1999, s. 507; Regime, http://www.biology-online.org/dictionary/Regime, o6.11.2012 r.

${ }^{4}$ R.E. Lane, Jak uwolnić politologię od niej samej?, [w:] Psychologia polityczna, red. D. O. Sears, L. Huddy, R. Jervis, Kraków 2008, s. 691-717. 
ści psychologię. Ta ostatnia określa przedmiot poznania politologii. W tym ujęciu politologia jest tożsama $\mathrm{z}$ analizą interesów. Wyniki badań Davida O. Searsa, na przekór teorii racjonalnego wyboru, świadczą o tym, że jednostka głosuje kierując się raczej hasłami, ideologią niż osobistymi zyskami i stratami. Jeśli już „perspektywa portfela” ma istotne znaczenie, to tylko w ramach aktywizacji wstępnej, czyli momencie zainteresowania bodźcem. Uwaga jednostek kierowana jest na bieżące sprawy, co nie powoduje tworzenia opinii dotyczących długofalowej polityki.

R. E. Lane podkreśla również istotność „logiki instytucji” jako kolejnego obszaru zainteresowania politologii. Definiuje logikę instytucji jako „zamierzone i niezamierzone konsekwencje ludzi, reguł, procedur i zasobów zaangażowanych w danym kontekście w określoną misję realizowaną przez organizację"5. Człowiek musi zatem odnaleźć się pośród szeregu misji i wartości, które kształtują organizację. Przymus wynika z ryzyka, że pozbawiony świadomości i wagi misji członek danej instytucji może nie działać według jej „logiki”. Według indywidualistycznego podejścia, zaprezentowanego w artykule, jednostki głosują biorąc pod uwagę interes własny ${ }^{6}$. Celowo podkreślam indywidualizm, gdyż R. E. Lane zauważa, iż jeśli przedstawiciele biedniejszych warstw społecznych będą kierowali się poczuciem osiągnięcia w przyszłości lepszej pozycji, mogą zagłosować np. przeciwko redystrybucji. Z tym wiąże się niezwykle ważna kwestia w psychologii, a mianowicie poczucie odpowiedzialności za swój los, a także dyspozycje.

Nie sposób w tym miejscu nie nawiązać również do teorii atrybucji. Ludzie bowiem mogą wnioskować o przyczynach czyjegoś zachowania lub zaistnienia sytuacji na podstawie czynników zewnętrznych, jak i wewnętrznych ${ }^{7}$. W pierwszym przypadku mowa o atrybucji zewnętrznej, co skutkuje myśleniem o sprawczości przyczyn związanych z sytuacją, losem, obecności pecha, szczęścia, oddziaływań fortuny itd. W drugim przypadku zajdzie interpretacja upatrująca przyczyny zachowania w czynnikach osobowościowych obserwowanej jednostki, co będzie realizacją atrybucji wewnętrznej. Jest to również uzależnione kulturowo, więc w przypadku opisywanych przez R. E. Lane’a przykładów z kultury anglosaskiej, oczekiwać należy raczej stosowania atrybucji wewnętrznych. Identyfikowanie przyczyn zachodzenia zja-

${ }^{5}$ Ibidem, s. 698-699.

${ }^{6}$ Wyjaśniono już, że niekoniecznie jest on stricte związany ze sferą finansową.

${ }^{7}$ E. Aronson, T. D. Wilson, R. M. Akert, Psychologia społeczna. Serce i umyst, Poznań 1997, s. 187-201. 
wisk wyłącznie w cechach osobowości bywa przeceniane, co zostało sformułowane jako podstawowy błąd atrybucji ${ }^{8}$.

Psychologia udziela także odpowiedzi na bardziej generalne problemy, np. poczucie kontroli nad własnym losem. Jednym z nich jest kwestionariusz „Delta” autorstwa Radosława Ł. Drwala. Na jego podstawie można określić stopień wewnątrz- i zewnątrzsterowności jednostki ${ }^{9}$.

Badania Daniela Katza i współpracowników pozwoliły zdiagnozować, iż wrażenia Amerykanów dotyczące działalności instytucji biurokratycznych (usługowych, m.in. w zakresie: opieki społecznej, emerytur, służby zdrowia, zatrudnienia) zaprzeczają ogólnie dostępnemu stereotypowi ${ }^{10}$. Osoby badane odpowiedziały, że urzędnicy byli przyjaźni, że sprawy urzędowe były doprowadzone do końca, prezentowali się również jako osoby kompetentne ${ }^{11}$.

Procesy polityczne stanowią według R. E. Lane’a kolejną kategorię zainteresowań politologii ${ }^{12}$. Aby uzasadnić związek procesów psychologicznych z procesami politycznymi, stworzył specjalną macierz. Wyróżnił w jej ramach: wyborcze, ustawodawcze i sądowe procesy polityczne. Procesy psychologiczne podzielił również na trzy subkategorie: wybrane procesy poznawcze, „osobowość a polityka” oraz wzbudzenie emocjonalno-motywacyjne ${ }^{13}$.

${ }^{8}$ W. Domachowski, Przewodnik po psychologii spolecznej, Warszawa 2007, s. 122.

${ }^{9}$ S. Siek, Wybrane metody badania osobowości, Warszawa 1993, s. 435-438.

${ }^{10}$ R. L. Kahn, D. Katz, B. Gutek, Bureaucratic Encounters - An Evaluation of Government Services, „The Journal of Applied Behavioral Science” 1976, nr 12, s. 178-198.

${ }^{11}$ R.E. Lane, op. cit., s. 702.

${ }^{12}$ Ibidem, s. 703-704.

${ }^{13}$ Nie określił jednak klucza doboru poszczególnych procesów psychologicznych. Do grupy procesów poznawczych zaliczył heurystykę dostępności skorelowaną z wyrazistością bodźca (czyt. oferty politycznej), z drugiej strony powodującą wytworzenie się „niepostawy” wobec bodźca mniej wyrazistego. Ta podgrupa jest istotna dla procesów wyborczych. Dysonans poznawczy (wymiar lojalność - nielojalność przedstawicieli elit politycznych wobec własnej partii, ideologii) oraz specyfika orientacji lidera politycznego (solidarność grupowa - zadaniowość), wpływają według R. E. Lane’a na procesy ustawodawcze. Na procesy sądowe wpływa myślenie linearne lub asocjacyjne. Drugą grupę stanowią czynniki osobowościowe. W procesach wyborczych zasadnicze znaczenie ma wymiar ekstrawersji i neurotyzmu oraz zbliżanie się do innych lub unikanie innych. W procesach ustawodawczych osobowości znaczenie ma domniemany autorytaryzm lub egalitarność urzędników państwowych. Podobnie w procesach sądowych egalitaryzm sędziego może rzutować na podejmowane decyzje. Ostatnią grupę stanowi wzbudzenie emocjonalno-motywacyjne. Biegunowy układ afektu szczęśliwy - nieszczęśliwy może wpływać na procesy wyborcze, motywacja osiągnięć rzutuje zaś na procesy ustawodawcze, a poznawcza zdolność oceny emocji ma wpływ na pracę sędziego. 
Politologia w ujęciu R. E. Lane’a zajmuje się również analizą władzy. Oczywiście, brzmi to jak truizm ${ }^{14}$. Z tą różnicą, że politologia oparta na psychologii rozpatruje to zjawisko pod innym kątem. Otóż strona posiadająca władzę może być zorientowana na rezultat. Wtedy władza stanowi środek do osiągnięcia zamierzonego celu. Może jednak stanowić cel sam w sobie.

Przywołać można również eksperyment Davida Kipnisa, w którym sprawdzano, jak grupa eksperymentalna (mająca możliwość nakładania kar na uczestników zadania), w porównaniu z grupą kontrolną (mogącą w stosunku do podwładnych używać jedynie argumentacji), skorzysta z przysługujących jej uprawnieńn ${ }^{15}$. Dodatkowo mierzono chęć nawiązywania stosunków społecznych z pracownikami. Okazało się, że posiadanie instrumentów władzy zwiększało chęć wywierania wpływu na zachowania podwładnych ${ }^{16}$. Używanie jednak uprawnień władczych zwiększało przekonanie, że modyfikacja zachowania pracowników jest uzależniona od rozkazów autorytetu. Skutkowało to tym, iż osiągnięcia podwładnych były deprecjonowane. To z kolei powodowało zwiększenie się dystansu społecznego do osób kontrolowanych.

\section{TO CO POLITYCZNE, CZYLI TO, CO GRUPOWE?}

WSPOMNIANO WYŻEJ O DEFINICJI OBSZARU ZAINTERESOWAŃ POLITOLOGII autorstwa R. Skarzyńskiego. Warto się jej bliżej przyjrzeć. Genetycznie patrząc, autor wychodzi od cech teorii politologii, która według niego określa przedmiot poznania (czyt. „to, co jest polityczne”) jako „szczególną składową [zmieniono formę gramatyczną - przyp. M. B.] tego, co społeczne (czyli składową, której wyłonienie w ramach tego, co społeczne powoduje, że ludzkie zgrupowania, w tym całe społeczeństwa, funkcjonują inaczej, aniżeli funkcjonowały wcześniej, gdy jeszcze to, co polityczne, nie występowało)" ${ }^{17}$. Jednym z problemów opisywanych i analizowanych przez autora jest ów moment, w którym to, co społeczne, staje się polityczne oraz problematyka wyodrębnienia owego

${ }^{14}$ Por. A. Heywood, Politologia, Warszawa 2010, s. 264-267.

${ }^{15}$ D. Kipnis, Does power corrupt?, „Journal of Personal and Social Psychology” 1972, nr 24, s. 33-41.

${ }^{16}$ R. E. Lane, op. cit., s. 706.

${ }^{17}$ Dodatkowo badacz zaznaczył (chociaż to jest oczywiste samo przez się), iż teoria politologii rozumie cechy i znaczenie przedmiotu badań, jak i że obszar jej zainteresowań jest swoisty tylko dla niej, i który jako taki nie funkcjonuje w innych naukach (z zaznaczeniem odrębności od socjologii). Zob. R. Skarzyński, op. cit., Białystok 2012, s. 273. 
„przejścia” między dwiema strukturami ${ }^{18}$. Struktury nazywa R. Skarzyński „zjednoczeniami” lub „zgromadzeniami”. Owe zjednoczenia polityczne dzieli na podmioty polityczne i środki polityczne ${ }^{19}$. R. Skarzyński określa: „Byt społeczny, który nie aspiruje do ustanowienia porządku świata dla poruszającej ludzkie uczucia, nie jest bytem politycznym, nawet jeśli wartość jego produktu przekracza całkowitą wartość produktu szeregu państw”"

Wypada w tym miejscu przytoczyć następny fragment pracy, ponieważ dotyczy on predyspozycji, cech osób, które tworzą to, co polityczne. R. Skarzyński pisze: „Gdy takim zgrupowaniom osobników, nierzadko ambitnym i walecznym, brak wizji, skupiającej uczucia jednoczącej członków zbiorowości w sposób pozwalający uderzyć każdym środkiem, nie działają one z powołania i nie są zjednoczeniami politycznymi” ${ }^{21}$. Dalej czytamy: „Politologia, pomimo upartych działań politologów obracających własną dyscyplinę w potoczną wiedzę o społeczeństwie, nie może degenerować się do roli pseudonauki kopiującej «podejścia» historyczne, prawnicze, psychologiczne czy socjologiczne, ale powinna korzystać z dorobku tych nauk w zakresie pomocniczym”22. Tym samym, warto sprawdzić i spróbować odpowiedzieć, w jakim zakresie i jak na takie podejście definicyjne w określeniu „politycznego" odpowiedzieć może psychologia.

Przede wszystkim definicja zaproponowana przez R. Skarzyńskiego określa polityczne jako twór zbiorowy, a dokładniej rzecz ujmując, jako grupę społeczną. Stanowi o tym „wspólna wizja” i „dążenie do jej realizacji”. Tercet amerykańskich naukowców, którzy napisali jeden z ważniejszych podręczników psychologii społecznej, pt. Psychologia społeczna. Serce i umyst, określił, że jest to „grupa, w której dwie lub więcej osób współdziała ze sobą oraz współzależy od siebie w tym sensie, że w zaspokajaniu potrzeb i osiąganiu celów musi na sobie polegać [podkr. M. B.]"23. Pomijam celowo

\footnotetext{
${ }^{18}$ Może być bowiem tak, że grupa jest tworzona od początku po to, aby realizować „polityczne”.

${ }^{19}$ Podmiot polityczny stanowi struktura mogąca dysponować, rozporządzać każdym zasobem i siłą, umożliwiającymi realizację jego celów w szerokiej skali (makrospołecznej). Środek polityczny stanowi zaś instrument, którym podmiot polityczny posługuje się. Zob. ibidem, s. 292-293.

${ }^{20}$ Ibidem, S. 292.

${ }^{21}$ Ibidem, s. 301.

${ }^{22}$ Ibidem, s. 305.

${ }^{23}$ E. Aronson, T. D. Wilson, R. M. Akert, op. cit., s. 357. Istnieją również inne definicje, jak chociażby ta zaproponowana przez Rupperta Browna. Twierdzi on, że „o grupie
} 
rozważania na temat licznych typologii, omawiających różnorakie właściwości grupy społecznej jako takiej, gdyż nie jest to przedmiotem tej pracy $^{24}$. Grupy można opisywać, skupiając się na ich: wielkości, rolach, statusie, relacjach interpersonalnych, interakcjach, celach, dynamice (zmianach okresowych), a także obowiązujących w niej normach ${ }^{25}$. Ponadto, należy skupić się na tym, co stanowi polityczne, a nie jego otoczenie, czyli to, co społeczne ${ }^{26}$.

Te specyficzne zjednoczenia mają określone cele, które odróżniają je od innych zgrupowań. Właściwie owe cele stanowią motywację do działania, funkcjonowania tych grup. Trudne cele powodują wzrost produktywności grupy ${ }^{27}$. W przypadku identyfikowania politycznego z tym co społeczne, cele stanowią o spójności grupy. Czytamy, że mobilizacja polityczna „to szczególny stan zjednoczenia ludzi, ujawniający się w tak intensywnej koncentracji i polaryzacji ich stosunków, że przeobrażają się [one - przyp. M. B.] w podmiot zdolny z powołania posłużyć się wszelkimi środkami, aby walczyć o ustanowienie $\mathrm{w}$ wielkiej przestrzeni powszechnego porządku wedle wyznawanej jego wizji” ${ }^{28}$. Przyświeca im zatem szczególna determinacja, aby owe cele osiągnąć. Spójność tej grupy musi zatem zachodzić w stopniu wysokim. Warte przypomnienia jest, że według psychologów spójność jako cecha składa się z takich elementów, jak: solidarność grupowa, lojalność, myślenie o zespole i myślenie w kategoriach „my”. Ponadto wyniki badań pokazują, że istnieje związek pomiędzy spójnością grupy a jej skutecznością ${ }^{29}$. Istotne jest jednak, aby w grupie obowiązywały normy nakazujące skuteczne działanie ${ }^{30}$. Członkowie grupy muszą być zaangażowani, aby owa spójność była utrzymana, a co za tym idzie, skuteczne działanie i realizacja planu w zakresie makro zmiany rzeczywistości zgodnie z własnym interesem.

mówimy wówczas, kiedy dwie osoby lub więcej osób określa siebie jako jej członków oraz kiedy jej istnienie jest rozpoznawalne przez przynajmniej jaką́ inną jednostkę". Zob. R. Brown, Procesy grupowe. Dynamika wewnątrzgrupowa i międzygrupowa, Gdańsk 2006, s. 18-19.

${ }^{24}$ Grupy można klasyfikować ze względu na różne kryteria. Do popularnych należą: kryterium wielkości (małe, duże), stopień sformalizowania (formalne, nieformalne) itp. Zob. B. Wojciszke, D. Doliński, Psychologia społeczna, [w:] Psychologia akademicka. Podręcznik, red. J. Strelau, D. Doliński, T. 2, Gdańsk 2010, s. 406-408.

${ }^{25}$ Zob. C. K. Oyster, Grupy, Poznań 2002, s. 21-52.

${ }^{26}$ Wyróżnik istotny za R. Skarzyńskim podałem wcześniej.

${ }^{27}$ Ibidem, S. 49.

${ }^{28}$ R. Skarzyński, op. cit., s. 292-293.

${ }^{29}$ B. Wojciszke, D. Doliński, Psychologia społeczna..., op. cit., s. 408-409.

${ }^{30}$ B. Wojciszke, Psychologia spoleczna, Warszawa 2011, s. 458-459. 
Funkcjonowanie grupy niesie za sobą jednak określone problemy. Także i w tej kwestii psychologia staje się pomocnym pryzmatem ${ }^{31}$. Jednym z opisywanych wymiarów grup społecznych jest rola, jaką członkowie grupy muszą podjąć. Znów przychodzi w tym miejscu podkreślić silną determinację jednostek tworzących owe specyficzne zgromadzenia. Biorąc pod uwagę ów aspekt, należy wskazać, że w przypadku prób odgrywania przez jednostki ról indywidualnych może dojść do konfliktu pomiędzy poszczególnymi kreacjami, co może skutkować dezorganizacją grupy, a nawet jej paraliżem ${ }^{32}$. Carol K. Oyster wyróżnia kilka rodzajów grupowych ról ${ }^{33}$. Agresorem jest osoba, która wywołuje konflikty, a także lubi toczyć spory. Istnieje również ryzyko, że zadania zostaną opóźnione przez brak konsensusu, który uniemożliwia postać negatywisty. Osobę, która forsuje tylko swoje rozwiązania i jest jednocześnie zamknięta na propozycje płynące od innych osób C. K. Oyster określa mianem dyktatora. Łowca sukcesu to osoba, której celem jest znalezienie się w grupie osób będących autorami jakiegoś osiągnięcia. Ekshibicjonistę zaś charakteryzuje skłonność do zwracania na siebie uwagi, jak i do zwierzania się z faktów ze swojego życia. Remedium na te problemy jest odpowiednie kierowanie grupą przez jej przywód$\mathrm{cę}^{34}$.

${ }^{31}$ Rzecz jasna, ten wątek stanowi przede wszystkim krótki przegląd sytuacji zagrażających grupie.

${ }^{32}$ C. K. Oyster, op. cit., s. 36.

${ }^{33}$ Ibidem.

${ }^{34}$ Istnieje szereg koncepcji opisujących, czym powinien charakteryzować się dobry przywódca. W celu zasięgnięcia wiadomości na ten temat, można odwołać się do perspektywy Marka Leary'ego, według którego idealny przywódca jest: moralny, silny, kompetentny, sympatyczny (wzbudzający sympatię), onieśmielający. Można także odwołać się do sondażu i na bieżąco kreować wizerunek przywódcy, aby był tożsamy z oczekiwaniami, które mogą z kolei cechować się dynamiką, ponieważ przewodzenie to właściwie uczestniczenie $\mathrm{w}$ procesie kierowania organizacją. Można również nawiązać do tendencji kategoryzowania oraz posługiwania się heurystykami przez ludzi. John L. Sullivan, John H. Aldrich, Eugene Borgida i Wendy Rahn zaproponowali model supermana/przeciętniaka w kreowaniu wizerunku przywódcy. To również jest uzależnione od zmieniających się okoliczności, oczekiwań członków grupy. David Krech, Richard S. Crutchfield i Egerton L. Ballachey wymienili aż 14 funkcji, które musi spełnić idealny przywódca. Kierujący grupą powinien być: 1. koordynatorem działalności grupy, 2. osobą ustalającą cele i politykę grupy, 3. człowiekiem planującym sposoby i środki do osiągnięcia celu grupowego, 4. ekspertem, 5. reprezentantem grupy na zewnątrz, 6. kontrolerem stosunków wewnątrzgrupowych, 7. osobą rozdającą nagrody i kary, 8. arbitrem i mediatorem, 9. wzorem zachowania się dla innych członków grupy, 10. symbolem grupy, 11. człowiekiem, który zwalnia od odpowiedzialności innych członków grupy, ponieważ sam podejmuje decyzje, 12. ideologiem grupy, 13. postacią „ojca” (nawiązanie do teorii psychoanalitycznej), z którą członkowie grupy są uczuciowo związani i z którą 
W sukurs pragnącym zbadać konstelację stosunków wewnątrzgrupowych przychodzi ponownie psychologia. Nie chodzi w tym miejscu bynajmniej o podkreślenie roli w badaniu grup społecznych jako takich, lecz istotne jest, aby to, co polityczne było w stanie samo kontrolować stosunki panujące wewnątrz grupy. Wszystko po to, co podkreślam jeszcze raz, aby nie stało się ono tym, co społeczne.

W tym sensie bardzo pomocnym narzędziem w określeniu stanu grupy jest analiza struktury socjometrycznej. Za twórcę socjometrii uważa się Jakuba L. Moreno, który za naturalne, permanentnie związane z życiem jednostek, uważał dokonywanie wyborów (ludzi i rzeczy) w sposób świadomy lub nieświadomy dopóki jest to zgodne z ich własnym $\mathrm{Ja}^{35}$. Stanisław Mika pisał, że strukturę socjometryczną okre-

się identyfikują, 14. „kozłem ofiarnym”, na którego grupa zrzuca odpowiedzialność za niepowodzenia, które ją spotkały.

Przywództwo, według Margaret G. Hermann i Thomasa Prestona, składa się z pięciu elementów: zakres zainteresowań politycznych (np. polityka skoncentrowana na wybranych zagadnieniach lub polityka globalna), stopień tolerancji konfliktów, typ motywacji (np. ideologia, normy, poczucie misyjności), strategia gromadzenia informacji (w rozumieniu gromadzenia informacji interesujących przywódcę zagadnieniach, np. poleganie na wybranych autorytetach), sposoby rozwiązywania konfliktów (może prezentować styl argumentacyjny, konsensualny, czasami zaś realizuje postawę arbitra w wewnętrznym sporze, jak i może uznać, że efektywne z jego lub/i grupy interesu będzie nieangażowanie się w konflikt).

Występują również różne style kierowania. Najbardziej znany podział autorstwa Rona Lippitta i Roberta White'a (działających z inspiracji i pod kierownictwem Kurta Lewina) obejmuje styl autokratyczny, demokratyczny oraz pośredni liberalny. Pierwszy z nich charakteryzuje się tym, że zadania są zlecane grupie przez przywódcę, który nie bierze udziału w pracach. Taki przywódca wykazuje się tendencja do stosowania wzmocnień negatywnych niż pozytywnych. Styl demokratyczny cechuje stosowanie wzmocnień pozytywnych wobec grupy. Jest ona także zachęcana przez przywódcę do ustalania celów oraz decydowania, które z rozwiązań przyjąć jako optymalne. Trzeci styl jest hybrydą między dwoma poprzednimi. W tym sensie przywódca traktuje grupę bardziej towarzysko, nie wykazuje tendencji do ewaluowania pracy podwładnych, w związku z tym członkowie grupy odczuwają największy zakres poczucia wolności, co koreluje ujemnie z efektywnością wykonywania zadań. Zob. W. Cwalina, A. Falkowski, Marketing polityczny. Perspektywa psychologiczna, Gdańsk 2006, s. 177-189; M. G. Hermann, T. Preston, Presidents, Advisers, and Foreign Policy: The Effect of Leadership Style on Executive Arrangements, „Political Psychology” 1994, nr 15, s. 7595; U. Jakubowska, Przywództwo polityczne, [w:] Podstawy psychologii politycznej, red. K. Skarżyńska, Poznań 2002, s. 82-106; S. Mika, Wstęp do psychologii spolecznej, Warszawa 1975, s. 266-282; C. K. Oyster, op. cit., s. 249-257; B. Wojciszke, Psychologia społeczna..., op. cit., s. $445-448$.

${ }^{35}$ Zob. A. Brzezińska, Socjometria, [w:] Metodologia badań psychologicznych: wybór tekstów, red. J. Brzeziński, Warszawa 2006, s. 192. 
ślają stosunki panujące w grupie ze względu na przyjęte kryterium, także „lubienia lub nielubienia” ${ }^{6}$. Jak to się ma do „politycznego”?

Otóż socjometria pozwala przede wszystkim wyróżnić jednostki, które: cechują się specyficznymi przymiotami, właściwościami; wymagają specjalnego sposobu postępowania (np. wzmacniającego ich dobre zachowanie lub oddziaływań o charakterze wychowawczym); są atrakcyjne dla członków grupy; są odrzucane, izolowane ${ }^{37}$.

Wymienia się także szereg korzyści, „efektów” zastosowania badania socjometrycznego ${ }^{38}$. W sensie ogólnym grupa dowiaduje się, jaki „wizerunek” zrzeszenia tworzy, biorąc pod uwagę własną perspektywę. Następnie istotne z punktu widzenia efektywności funkcjonowania grupy jest to, jakimi kryteriami posługują się jej członkowie, czy są to kryteria subiektywne czy obiektywne. Ponadto, analiza umożliwia sprawdzenie, czy zachodzi odpowiedni dobór jednostek do poszczególnych zadań. Może się bowiem okazać, że pewne osoby przydzielane są do zadań przekraczających ich zasoby, co skutkuje spadkiem efektywności grupy, jak i zaangażowania jej członków339.

Grupy istnieją w określonym stadium. Wyróżnia się stadia: 1. grupa młoda, początkująca, niedojrzała; 2. grupa dorastająca, poszukująca swej tożsamości; 3. grupa stara, rozpadająca się; 4. grupa dorosła, dojrzała, stabilna ${ }^{40}$. Według charakterystyk poszczególnych rodzajów, „polityczne” zjednoczenie musiałoby się charakteryzować „sztywnością funkcjonalną służącą realizacji ważnych dla grupy celów rozwojowych”, jak i „silną potrzebą jasności, jednoznaczności, jednorodności”. Członkowie grupy winni „odczuwać siłę grupy”, co wpływa na symboliczną identyfikację z nią. Powinna ona zatem skrócić maksymalnie czas stadium pierwszego, a także nie powinna dopuścić do zaistnienia stadium drugiego i trzeciego ${ }^{41}$. Celem zatem grupy jest nieustanne funkcjonowanie w stadium 4. Anna Brzezińska wymienia jego cechy:

\footnotetext{
${ }^{36}$ Ibidem, s. 193 .
}

${ }^{37}$ Ibidem, s. 202.

${ }^{38} \mathrm{~W}$ poniższym akapicie wszelkie cytowania, odwołania można odnaleźć w tekście A. Brzezińskiej. Zob. ibidem, s. 228-231.

${ }^{39}$ Odnośnie tego punktu, grupa musi przede wszystkim zadbać o to, aby nie dochodziło do niekorzystnych zjawisk, np. do „próżniactwa społecznego”. Definiuje się go jako spadek zaangażowania członków grupy w wyniku przekonania, że ocena ich indywidualnego działania jest utrudniana przez sam fakt uczestniczenia w działaniu grupowym (zbiorowym). Zob. E. Aronson, T. D. Wilson, R. M. Akert, op. cit., s. 364.

${ }^{40}$ A. Brzezińska, op. cit., s. 228-231.

${ }^{41} \mathrm{~W}$ cytowanej literaturze ujmowanych jako dwa podtypy stadium II. Z powodu jednak wyraźnie zakreślonych „granic” wyróżniam dwa osobne typy. 
„wyraźnie określone, elastyczne granice”, co jest tożsame z postulatem zachowania odpowiedniej dynamiki. Członkowie grupy charakteryzują się w tym stadium wzajemnym zaufaniem wobec siebie oraz wobec przywództwa grupy. Podzielają także wizję i cele działania grupy, jak i stosują się do obowiązujących w niej norm. W przypadku zajścia ewentualnych konfliktów wewnątrz grupy, sposoby jego rozwiązania są konstruktywne i opierają się na otwartości, zatem żaden z incydentów zagrażających grupie nie pozostaje nieprzedyskutowany. Zgodnie z interpretacją R. Skarzyńskiego, A. Brzezińska podkreśla dużą gotowość członków grupy do angażowania się w przedsięwzięcia. Przywódca grupy funkcjonuje zaś niejako „Z drugiego planu”42.

Godny uwagi jest również wymiar jednostkowy. Członek zjednoczenia politycznego musi charakteryzować się określonymi predyspozycjami osobowościowymi. Rozkład niektórych cech może sprawiać, że działania grup będą w pewien sposób ograniczone poprzez nieodpowiedni dobór kadr.

Klasycznymi koncepcjami omawianymi przez polskich psychologów politycznych są: pojęcie osobowości autorytarnej Theodora Adorno; teoria skryptów afektywnych Silvana Tomkinsa; ujęcie dogmatyzmu Miltona Rokeacha; teoria charakteru autorytarnego Ericha Fromma ${ }^{43}$. Wspomniano o nich celowo, ponieważ stanowią one kanon. Warto jednak zając się innymi wymiarami osobowości, które mogą mieć wpływ na funkcjonowanie grupy społecznej.

Jednym z potencjalnych zagrożeń dla integracji wewnątrzgrupowej jest poczucie kontroli nad własnym losem. Otóż, może być tak, iż człowiek identyfikuje siebie jako sprawcę swojego losu, czyli osobę będącą w stanie nim kierować, odpowiedzialną. Z drugiej strony, coś lub/i ktoś z zewnątrz może sterować losem jednostki. Wówczas mowa o zewnętrznym poczuciu kontroli. Wspomniany wyżej podział na atrybucje zewnętrzne i wewnętrzne jest bliski tej systematyce, ponieważ człowiek mający zewnętrzne poczucie kontroli będzie upatrywał rzeczywistość jako efekt działalności, np. losu, niesprzyjających okoliczności, działania drugiego człowieka itp. Według Abrahama Maslowa

${ }^{42}$ Por. z wcześniej wymienioną typologią stylów kierowania autorstwa R. Lippita i R. White'a.

${ }^{43}$ Zob. U. Jakubowska, Preferencje polityczne. Psychologiczne teorie $i$ badania, Warszawa 1999; U. Jakubowska, Przywództwo polityczne, [w:] Podstawy psychologii politycznej, red. K. Skarżyńska, Poznań 2002, s. 82-106; K. Korzeniowski, Autorytaryzm i jego psychopolityczne konsekwencje, [w:] Podstawy psychologii..., op. cit., s. 59-81; K. Skarżyńska, Człowiek a polityka. Zarys psychologii politycznej, Warszawa 2005 . 
człowiek „samorealizujący się” wyróżnia się specyficznymi cechami ${ }^{44}$. W porównaniu z „przeciętnymi ludźmi” ma lepszy kontakt z rzeczywistością, tzn. jego funkcjonowanie pozbawione jest odrealnienia, złudzeń. Niesie to za sobą określone konsekwencje w sposobie zmieniania rzeczywistości, co odbywa się za pomocą podejmowania prób, walki z nią, a nie „ucieczki w fantazjowanie”. Wiąże się to również z tym, iż akceptuje on w większym stopniu ułomności ludzkiej natury. Jest również bardziej zdeterminowany w kwestii realizowania planów oraz dopinania wyznaczonych sobie celów.

Podobnie, David Riesman określa człowieka wewnątrzsterownego jako osobę, której „dewizą życia jest wysiłek”45. Ponadto cechuje go zapał w realizowaniu przeobrażania przyrody, konstrukcji dużych organizacji. Człowiek zewnątrzsterowny według D. Riesmana skłania się w swoim funkcjonowaniu ku sytuacjom łatwym, niewymagającym wysiłku. Nie interesuje go zmiana rzeczywistości jako efekt własnych potrzeb. Te ostatnie bowiem wynikają z roli, którą owo „zewnętrzne” mu narzuca. W tym sensie gotów jest przyjąć każdą rolę, niejako zatracając w tym siebie. Może przejawiać „kult łatwego życia”46.

Poczucie umiejscowienia kontroli, może sprawiać, iż poszczególne jednostki mogą stanowić „hamulec” dla dokonywania zmian, wprowadzając ferment w myśleniu grupowym. Polega to na podkreślaniu ryzyka, ewentualnych kosztów potencjalnych działań. Nie jest to postawa równoznaczna z racjonalizowaniem, wynika bowiem z braku optymizmu, charakterystycznego dla człowieka pozbawionego chęci samorealizacji. Problematyczna pozostaje jednak kwestia badania tego wymiaru. Kwestionariusze „Delta”, Children's Nowicki-Strickland Internal-External Scale a także Stanford Preschool Internal External Scale oraz Kwestionariusz do Badania Poczucia Kontroli G. Krasowicz oraz A. Kurzyp-Wojnarskiej są przeznaczone do badania osób młodych, adolescentów lub późnych adolescentów ${ }^{47}$. Dla osób rekrutujących członków grupy należałoby zatem zbudować odrębne narzędzie w oparciu o rozwiązania zbliżone chociażby do kwestionariusza „Delta” 48 .

${ }^{44}$ S. Siek, Wybrane metody badania osobowości, Warszawa 1993, s. 434.

${ }^{45}$ Ibidem.

${ }^{46}$ Ibidem.

${ }^{47}$ Ibidem, s. 435-446.

${ }^{48}$ Wymienić warto kilka stwierdzeń wskazujących na zewnętrzne poczucie kontroli: „Niepowodzenia, które nas spotykają, to wina braku szczęścia.”; „Bardzo często czuję, że nie mam wpływu na to, co mnie spotyka.”; „Niektórzy są po prostu urodzonymi szczęściarzami.". Zob. ibidem, s. 435. 
Dość adekwatnym z punktu widzenia zgromadzenia politycznego jest udowodnione w badaniach zrównanie „pobudzenia” z koncepcji Hansa Eysencka z teorią „motywacji”, łączonej z prawem Yerkesa-Dodsona ${ }^{49}$. Koncepcja opiera się na trzech skalach, w skrócie PEN (Psychotyczność Ekstrawersja Neurotyzm), w której występuje kontinuum ekstrawersja-introwersja. Teoria ta wnosi również istotne rozróżnienie pomiędzy cechą (powtarzającym się zbiorem reakcji behawioralnych występujących w różnych sytuacjach) a typem (zbiorem cech; tworem nadrzędnym) $)^{50}$.

${ }^{49}$ C. S. Hall, G. Lindzey, J.B. Campbell, Teorie osobowości. Wydanie nowe, Warszawa 2006, s. 380-381.

${ }^{50}$ Człowiek charakteryzujący się wysokim poziomem ekstrawersji jest według $\mathrm{H}$. Eysencka: towarzyski, żywy, aktywny, asertywny, poszukujący doznań, beztroski, dominujący, niefrasobliwy, skłonny do ryzyka. Jednostka osiągająca wysokie wyniki w skali $\mathrm{N}$ wykazuje się następującymi cechami: lękowość, przygnębienie, poczucie winy, mający niską samoocenę, napięty, irracjonalny, nieśmiałość, kapryśność, emocjonalność. W skali P zaś cechami konstytuującymi temperament jednostki są: agresja, zimno, egocentryczność, bezosobowość, impulsywność, aspołeczność, nieempatyczność, twórczość, nieuleganie sentymentom.

W celu lepszego uzmysłowienia sobie interpretacji poszczególnych wymiarów, warto przytoczyć H. Eysencka, posługując się podręcznikiem do kwestionariusza. Człowiek introwertywny jest opisywany w taki oto sposób: „lubi zajmować się introspekcją, woli raczej czytać książki niż przebywać w towarzystwie, jest powściągliwy, przyjaciół ma niewielu, a w ich doborze jest bardzo wymagający. W działaniu nie jest impulsywny, można by powiedzieć, że na co dzień kieruje się maksymą: «Sto razy pomyśl, a raz zrób»”, a także „stara się planować z wyprzedzeniem, «spogląda, nim postawi krok» i nie ufa impulsowi chwili. Nie lubi podniecenia, podchodzi do spraw codziennych z należytą powagą i lubi uporządkowany tryb życia. Ściśle panuje nad swymi uczuciami, rzadko zachowuje się w sposób agresywny i nie traci łatwo równowagi. Można na nim polegać, jest trochę pesymistą i dużą wagę przywiązuje do norm etycznych”. Ekstrawertyk został scharakteryzowany jako człowiek, który „jest towarzyski, posiada wielu przyjaciół, odczuwa potrzebę prowadzenia rozmów z innymi ludźmi, nie lubi natomiast zajmować się czytaniem w samotności. Potrzebuje podniet z zewnątrz, działa pod wpływem sytuacji, w której aktualnie się znajduje. Ogólnie uważa się go za jednostkę impulsywną i działającą bez zastanowienia. Lubi zajmować się działalnością praktyczną. Zawsze posiada gotową odpowiedź na skierowane pod jego adresem uwagi. Lubi zmiany. Nie przejmuje się nigdy zbytnio z powodu doznanych niepowodzeń. Jest optymistycznie nastawiony w stosunku do przyszłości. Lubi być w ruchu, wykonywać prace ręczne. Łatwo wpada w gniew, jest agresywny. Jego życie uczuciowe nie jest poddane kontroli intelektu i obowiązujących w danym środowisku, powszechnie przyjętych zasad współżycia. Freud powiedziałby, że ten człowiek w postępowaniu swoim kieruje się przede wszystkim, lub nawet wyłącznie, zasadą przyjemności”, ponadto „wykorzystuje okazje, często naraża się na krytykę (...). Bardzo lubi robić kawały, na wszystko ma zawsze gotową odpowiedź i na ogół lubi zmiany; jest beztroski, niefrasobliwy (...) i lubi «śmiać się i być wesołym». Woli być w ruchu i działać, jest skłonny do agresji i łatwo traci równowagę; ogólnie mówiąc nie panuje zbytnio nad uczuciami i nie zawsze można na nim polegać”. Człowiek osiągający wysoki wynik w skali N przez H. Eysencka opisy- 
Otóż jeśli jednostka charakteryzuje się wysokim stopniem stabilnego ekstrawertyzmu, radzi sobie ona z zadaniami trudnymi, dlatego że występuje u niej słabe pobudzenie. Ekstrawertycy neurotyczni zaś radzili sobie lepiej z zadaniami łatwymi. Jednostki osiągające wysokie wyniki w tej skali potrzebują większej stymulacji niż introwertycy51. Ponadto, bodźce słabe wywołują ujemne emocje. W przypadku introwertyków zachodzi ryzyko, iż będą oni unikali stymulacji. W tym sensie niezwykle istotnym dla funkcjonowania grupy jest odpowiednie rozdzielanie zadań po to, aby jednostki wymagające większego pobudzenia były przydzielane do odpowiednich zadań. Jest to mierzalne za pomocą kwestionariusza EPQ-R, który jest dostępny także w polskiej adaptacji ${ }^{2}$.

Jednostki osiągające wysokie wyniki w skali $\mathrm{N}$ mają tendencję do ujawniania negatywnych emocji, takich jak lęk oraz charakteryzują się stałym napięciem emocjonalnym ${ }^{53}$. Skutkować to może przyjmowaniem ról grupowych wpływających na spowolnianie prac grupy, $\mathrm{np}$. roli negatywisty.

W przypadku osób odznaczających się wysokim wynikiem w skali P grupa spodziewać się może aspołecznego modelu funkcjonowania. $\mathrm{Z}$ drugiej strony jednak wysokie wyniki w tej skali korelują dodatnio

wany jest jako ,jednostka lękowa, martwiąca się różnymi rzeczami, ulegająca nastrojom i często przygnębioną. Może on źle sypiać i mieć rozmaite dolegliwości psychosomatyczne. Jest nadmiernie emocjonalny, reaguje zbyt silnie na wszelkiego rodzaju bodźce i z trudem wraca do równowagi po każdym przeżyciu wzbudzającym emocje. Jego silne reakcje emocjonalne kolidują z jego odpowiednim przystosowaniem się, co sprawia, że reaguje on w irracjonalny, nieraz sztywny sposób. (...) Gdybyśmy mieli opisać człowieka mającego wysoki wynik na skali $\mathrm{N}$ w kilku słowach, moglibyśmy powiedzieć, że jest to człowiek wiecznie zmartwiony; jego główną cechą jest stałe zaabsorbowanie sprawami, które mogą się nie powieść oraz silna lękowa reakcja emocjonalna na te myśli. Z drugiej strony, człowiek stabilny reaguje emocjonalnie powoli, na ogół słabo i wraca do punktu wyjścia szybko po pobudzeniu emocjonalnym; jest zazwyczaj spokojny, zrównoważony, opanowany i nie martwi się". Według H. Eysencka, jeśli osoba osiąga wysokie wyniki w skali P, jest charakteryzowana jako człowiek „samotny, nie dbający o ludzi; jest on często uciążliwy, nie pasuje nigdzie. Może być okrutny i nieludzki, pozbawiony uczuć i empatii oraz całkowicie wyzuty z wrażliwości. Jest wrogi wobec innych, nawet swoich najbliższych, i agresywny w stosunku do tych, których kocha. Ma upodobanie do rzeczy dziwnych i niezwyczajnych, i nie liczy się z niebezpieczeństwem; lubi okpiwać innych ludzi i denerwować ich”. Zob. ibidem, s. 362-373; P. Brzozowski, R. Ł. Drwal, Kwestionariusz Osobowości Eysencka. Polska adaptacja EPQ-R. Podręcznik, Warszawa 1995, s. 15.

${ }^{51}$ J. Strelau, Psychologia różnic indywidualnych, Warszawa 2002, s. 230-231.

${ }^{2}$ A. Jaworowska, EPQ-R - Kwestionariusz Osobowości Eysencka EPQ-R. Kwestionariusz Osobowości Eysencka w Wersji Skróconej EPQ-R(S), Warszawa 2011.

${ }^{53}$ J. Strelau, op. cit., s. 230-231. 
z takimi, jak niekonwencjonalność, dezaprobata dla innych oraz negatywizm, a zatem istnieje ryzyko, iż te osoby są dewiantami grupowymi.

Ponadto, z psychotycznością oraz neurotycznością koreluje osobowość makiaweliczna ${ }^{54}$. Stanowi ona charakterystyczny układ cech oraz wizji świata. Makiawelista uważa bowiem świat za twór niesprawiedliwy oraz zły55. W kontaktach interpersonalnych wykazuje się skłonnością do manipulowania innymi, co wiąże się z nieustającą nieufnością. Główną motywacją jest realizacja własnych celów i interesów, co skutkuje tym, iż kontakty osobiste są mocno ograniczone poprzez brak umiejętności przyjmowania perspektywy drugiej jednostki. W przypadku występowania tego typu osobowości spodziewać się można również braku empatii. Normą obowiązującą dla tego typu ludzi jest zasada „cel uświęca środki”. Metodą badania występowania tej osobowości jest skala MACH IV lub MACH V56. W związku z powyższym, należy mieć na uwadze, iż jednostki będące makiawelistami mogą przyjmować role grupowe, które charakteryzują się forsowaniem własnych norm, celów, poglądów. Jedną z nich jest wspomniana wyżej rola grupowego dyktatora, co z kolei negatywnie wpływa na motywację do pracy członków grupy. Dodatkowo, jako że udowodniono, iż z makiawelizmem wiąże się kilka typów zaburzeń osobowości, można przyjąc tezę, iż obecność tego typu jednostek zagraża wspólnocie grupowej, a także jej członkom ${ }^{57}$.

\section{Podsumowanie}

BIORĄC POD UWAGE KRYTERIUM TEGO, CO POLITYCZNE, a co zOstało sformułowane w formie postulatu R. Skarzyńskiego, psychologia służy wyjaśnieniu, określeniu granic, a także sprzyja podtrzymywaniu tożsamości owych zgromadzeń. Zwłaszcza ten ostatni atrybut psychologii jest istotny, ponieważ pozwala oddzielić to, co polityczne od tego, co społeczne lub - inaczej - pozwala oddzielić „polityczne” od otoczenia. Grupy posiadające specyficzne cechy konstytuujące „polityczne”

${ }^{54}$ I. Pilch, Makiawelista wśród ludzi. Nowe badania, „Psychologia Społeczna” 2008, Tom 3, s. 232.

55 A. Siwy-Hudowska, A. Kieszkowska-Grudny, Osobowość makiaweliczna i jej czynniki $w$ porównaniach międzyptciowych: znaczenie inteligencji emocjonalnej i lęku, „Psychologia Społeczna”, t. 5, s. 27.

${ }^{56} \mathrm{Z}$ zastrzeżeniem, iż ta ostatnia wyróżnia się jednak mniejszą rzetelnością. Zob. ibidem, s. 31.

${ }^{57}$ Mowa tu o zaburzeniach osobowości, np. paranoidalnej, antyspołecznej, pogranicznej, pasywno-agresywnej. Zob. I. Pilch, op. cit., s. 238; L. Cierpiałkowska, Psychopatologia, Warszawa 2011, s. 307-316. 
są skazane na zapoznanie się z owym psychologicznym pryzmatem, aby ich tożsamość została zachowana. Pokazano wyżej, chociaż w niezwykle skrótowej formie, jak psychologicznie funkcjonować mogą członkowie grupy społecznej, ale i na jakie cechy jednostkowe należy zwrócić szczególną uwagę ${ }^{58}$.

Tytułem zakończenia warto przywołać dość optymistyczne dla wizji mariażu politologii z innymi dziedzinami zdanie R. Skarzyńskiego. Pisze on: „Określenie politologii jako dyscypliny naukowej nie pociąga za sobą postulatu zamykania się wobec innych dyscyplin, tylko oznacza konieczność otwarcia na nie z perspektywy własnego przedmiotu poznania" 59 . W tym rozumieniu tkwi dość wyraźna szansa dla psychologii polityki, jako tej dziedziny, która łączy dwie dyscypliny. Powyżej zwrócono uwagę na elementy zagrażające istnieniu integralności tego, co R. Skarzyński określa mianem „politycznego”. Środkiem zabezpieczającym i koordynującym może być psychologia polityki z jej narzędziami i specyfiką patrzenia na życie polityczne ${ }^{60}$.

W tej pracy sformułowano bardziej pole hipotez (ale i zbiór refleksji) wynikających z lektury Podstawowego dylematu politologii. Politologia mogłaby eksplorować owe obszary, aby mieć poczucie obecności granic, nawet jeśli to, co „polityczne” traktować zaczęłaby wyłącznie zgodnie z definicją przyjętą tutaj we wstępie. Czy bez narzędzi pomocniczych, charakterystycznych dla psychologii, badacz jest w stanie zweryfikować, czy jego przedmiot badań jest odmienny od tego, co społeczne? Granica może zostać określona, jeśli weźmie się pod uwagę chociażby zaprezentowane wyżej kryteria, pozwalające grupie społecznej odróżnić się od otoczenia.

\section{SUMMARY}

RYSZARD SKARZYNSKI THINKS that the main subject of recognition in political science have to be "the political", which is constructed by a specific kind of group. Contrary to this opinion R. E. Lane said that political science should be freed-up by political psychology. This kind

${ }^{58} \mathrm{~W}$ ramach zastrzeżenia dodać należy, iż oczywiste jest, iż forma artykułu nie przyzwala na określenie całego katalogu cech jednostkowych, które mogą wpływać (lub chociaż korelują) na określone typy relacji wewnątrzgrupowych. Traktuję więc tę pracę jako przedstawienie pewnego zarysu, a przede wszystkim głos w dyskusji.

${ }^{59}$ R. Skarzyński, op. cit., s. 306.

${ }^{60}$ Użyłem słowa „może”, ponieważ niniejsza praca nie stawia przecież tezy o patrzeniu wyłącznie przez jej pryzmat. 
of group ("political") is endangered by the roles played by individuals. Sociometry is a solution which helped to measure and explore the phase in which the group is. Personality is also important, because there are some characteristics which can threaten the whole group or the group's purposes (to stay "political" and not to become "social"). "Delta" questionnaire, EPQ-R, MACH IV should help the group and also political scientists to carry out the research what kind of individuals are members of the group. If political psychology has the best ways to explore this matter, political scientist should use them to distinguish "political" from "others".

\section{Nota O AUTORZE}

Michał Baluch [mbaluch@o2.pl] - absolwent politologii na WNPiD UAM i student psychologii w Instytucie Psychologii UAM, przewodniczący Koła Naukowego Psychologii Polityki (w latach 2008-2012); autor artykułów naukowych i recenzji dotyczących takich zagadnień, jak: stereotypy, kampanie negatywne, wizerunek medialny, wpływ społeczny, katastrofa smoleńska. 